\title{
The Role of Business Strategies and Financial Decisions in Preparing for International Market Entry and Improving SMEs' Performance: An Entrepreneurial Finance Perspective
}

\author{
Harjum Muharam ${ }^{1}$, Maria Rio Rita ${ }^{2}$, Isfenti Sadalia ${ }^{3}$, Asep Mulyana ${ }^{4} \&$ Mohamad Nur Utomo $^{5}$ \\ ${ }^{1}$ Faculty of Economics and Business, Diponegoro University, Indonesia \\ ${ }^{2}$ Faculty of Economics and Business, Satya Wacana Christian University, Indonesia \\ ${ }^{3}$ Faculty of Economics and Business, Sumatera Utara University, Indonesia \\ ${ }^{4}$ Faculty of Economics and Business, Universitas Padjadjaran, Indonesia \\ ${ }^{5}$ Faculty of Economics, Borneo Tarakan University, Indonesia \\ Correspondence: Maria Rio Rita, Faculty of Economics and Business, Satya Wacana Christian University, Jl. \\ Diponegoro 52-60 Salatiga 50711, Central Java, Indonesia. Tel: 62-81-5661-3050. E-mail: maria.rita@uksw.edu
}

Received: July 9, 2020

doi:10.5430/ijfr.v11n5p376
Accepted: September 10, 2020

Online Published: October 4, 2020

URL: https://doi.org/10.5430/ijfr.v11n5p376

\begin{abstract}
This paper strives to examine the role of international market entry in optimizing the effects of business strategies and financial decisions on SMEs' performance. In addition, this study analyzes the role of financing access in moderating the effects of business strategies and financial access. The research sample was comprised of 250 SMEs from various industries in the city of Salatiga, Central Java Province, and the city of Medan, North Sumatra Province, Indonesia. A Partial Least Squares (PLS) - Structural Equation Modelling (SEM) was utilized to test the hypotheses. In general, this research demonstrates that: (1) business strategies and financial decisions are the determinants of international market entry, (2) business strategies are a determinant of SMEs' performance, (3) business strategies and international market entry are factors of SMEs' performance, and (4) international market entry optimizes the effects of business strategies on SMEs' performance.
\end{abstract}

Keywords: business strategies, financial decisions, international market entry, financial access, SME performance

\section{Introduction}

\subsection{Introduction to the Problem}

Small and medium enterprises (SMEs) positively contribute to the aggregate economy of a country. The low productivity is a constraint for MSMEs to develop and reach a bigger economic scale. However, separate from low productivity, MSMEs have better endurance towards a crisis, which is due to their organizational structure and workforce. SMEs were better able to survive the economic crisis in the late 1990s than large firms mainly because SMEs rely more on local resources that are not affected by the global conditions (Ter Wengel \& Rodriguez, 2006). MSMEs are also more flexible in adjusting with market changes. This endurance and flexibility makes MSMEs used by the majority of society as the main source of livelihood. The role of SMEs in Indonesia's economy is supported by its population as the biggest business actor, as well as its contributions in exporting, absorbing the workforce, forming the gross domestic product (GDP), and creating fixed capital/ investments. In general, MSME performance is rather varied from year to year. Based on a report from the Ministry of Cooperatives and Small and Medium Enterprises of the Republic of Indonesia of 2018, the contribution of MSMEs in shaping the GDP (effective price) experienced a slight reduction from $61.41 \%$ in 2015 to become $60 \%$ in 2017. Besides that, the contribution figure of MSMEs in shaping the national GDP and non-oil and gas exports need to be improved from year to year, keeping in mind that the total MSMEs in Indonesia reaches $99 \%$ of the total business units. There is a rather large potential for Indonesian MSMEs to keep developing, so that maxium support is needed from the government and stakeholders. The productivity of the MSME sector per business unit experienced an increase of Rp. 27.93 million in 2015 to become Rp. 86.22 million in 2017. In contrast, the productivity per workforce increased from Rp. 13.43 million in 
2015 to become Rp. 46.50 million in 2017. In addition, this condition has also had an influence to the extent where SMEs in Indonesia can participate in production networks and the global market

Even in the broader scope, SMEs play an important role in supporting international trade (Knight, 2001). However, ironically, relatively few Indonesian SMEs participate in international trade, and the number of Indonesian SMEs that engage in international trade has been stagnant over the years. This fact is surprising because Indonesia has an abundance of natural resources that can potentially facilitate SMEs to contribute to the global market. Furthermore, a vast number of SMEs combined with heterogeneous resources offer significant internationalization potentials. In particular, only $10 \%$ of Indonesian SMEs have penetrated the global market, and the figure is dominated by medium-scaled firms (Uly, 2019).

SMEs can use export strategies to expand their market scopes for their business developments. The fact that only a small number of Indonesian SMEs have managed to engage in the global market indicates that they face serious obstacles. No single business model fits all firms (Brouthers \& Hennart, 2007) because each firm has its own dynamics and characteristics. Differences in business capacity and capability encourage SMEs to have unique strategies to enter the global market. Several previous studies have constructed the export business models of SMEs that fit different country-level conditions. For example, stark differences in the economic, political, cultural, and social aspects in Greek and Caribbean countries motivated L. E. Brouthers, Nakos, Hadjimarcou, and Brouthers (2009) to identify factors that explain SMEs' export success in both areas. Likewise, Wingwon (2015) formulated a business model to increase Thai MSMEs' competitive advantage through technological, innovative, and international support from the state. Meanwhile, the business model in Latin America includes both the driving and constraining factors of SMEs' export activities (Bianchi \& Wickramasekera, 2016), but they have not analyzed the impact of the business model on the overall business performance.

Discussions of SMEs' financial and business conditions are closely related to their financial aspect. One of the main obstacles that constrain SMEs' growth is insufficient capital. A basic difference between small firms and corporate firms lies in the magnitude of information asymmetry and agency problems between related parties. In particular, SMEs face greater pressures on both issues than corporate firms. Information opacity about SMEs' business prospects will potentially impair access to external financing. However, the strength of ties between SME owners likely increases SMEs' capabilities to exploit various opportunities (Kontinen \& Ojala, 2011), including financing ones. SMEs' financing sources are dominated by self-financing, which is less likely to be sufficient for all business needs. Consequently, SMEs will find it difficult to develop optimally, and eventually, their business scale will not grow significantly. In fact, when SMEs aim to enter the international market, they need more varied and greater resources than when they only serve the domestic market. More specifically, entrepreneurs should collaborate their resources of both tangible and intangible assets to create value. Capital is a tangible asset that is relatively flexible and requires reliable financial management.

Strong financial access likely moderates the impact of SMEs' business strategies and financial management on their efforts to enter the international market. Intensive financial support, both internally and externally, will stimulate the implementation of business strategies and further affect firms' financial activities. Entrepreneurs will be more flexible, creative, and innovative in formulating business strategies and management when they receive reliable financial support. Business strategies that facilitate SMEs' internationalization will improve SMEs' financial management when they have better financing access. The combination of sound financial management and reliable business strategies to achieve internationalization will improve SMEs' future financial performance. Morgan-Thomas and Jones (2009) investigated the dynamics of the post-entry phase of the internationalization of newly internationalized firms, especially the growth of international sales compared to the pre-internationalization effort. In particular, rapid international sales growth is closely related to the dependence on the main target country, high sales diversity within a country, and the dependence on information technology and computerization.

SMEs' financial management and decision making are largely done by their owners who also act as managers. Such characteristics imply that owners fully bear all business decisions and risks. Studies on business internationalization strategies have analyzed various perspectives. For example, Cadogan, Diamantopoulos, and Siguaw (2002) found that export experience, coordination capability, and export dependence are the antecedents of firms' export business strategies. Meanwhile, Salazar, Soto, and Mosqueda (2012) discovered no conformity between business strategies and SME owners' financial decisions. Besides that, the business ownership type determines the business strategy, where SMEs' internationalization strategy is negatively (positively) related to family (corporate) ownership (Fernández \& Nieto, 2006). However, only a few studies have analyzed export strategies, especially for Indonesian SMEs. Likewise, studies on the impact of business strategies and financial decisions on SMEs' international market 
entry still leave room for further investigation. Thus, this research constructs a business model to improve SMEs' internationalization performance that fits with the Indonesian business condition. Also, it is necessary to analyze the antecedents that affect the entry strategy of the international market to enable SME owners to have sufficient capacities and capabilities by considering their financial access.

\section{Literature Review and Hypotheses Development}

\subsection{Entrepreneurial Finance Theory}

The study of entrepreneurial finance is a collaboration of entrepreneurship and finance fields. The scope of this study is the level of small enterprises or those which are in the startup stage. This theory discusses the transformation of entrepreneurs' creative ideas to become business opportunities which result in business plans. Many dimensions are considered in managing a business, such as the financial aspect. Financial decisions such as payments and investments are one of the determinants of SME success. Differences in the company lifecycle/phase also cause differences in every financial decision or investment decision made by the firm (Leach \& Melicher, 2011), similarly with small enterprises. Moreover, it is added with the high level of information asymmetry and agency problems in small firms compared with established businesses (Mac an Bhaird \& Lucey, 2010). The magnitude of a constraint that is experienced by a small enterprise, whether regarding an agency issue or information asymmetry, has a greater effect than that felt by a big company. Therefore, the SME dynamic phenomenon is not appropriate if explained by using the corporate finance theory. In addition, the business strategies that are used by SMEs that are still operating at the local market scale will be different with SMEs that have started to penetrate the global market. More complex innovations and decision making are needed for SMEs which will do exporting (Love \& Roper, 2015).

Based on the literature review, this discussion about entrepreneurial finance can be seen from two perspectives, a demand/ SME entrepreneurial perspective (Briozzo \& Vigier, 2009; Maria Rio Rita \& Huruta, 2020; Maria Rio Rita \& Utomo, 2019) and supply/ financial intermediary perspective (Argerich, Hormiga, \& Valls-Pasola, 2013; Chemmanur \& Fulghieri, 2014; Kerr, Lerner, \& Schoar, 2014). This research specifically discusses about entrepreneurial finance from the SME actor side, in the context of SMEs preparing to enter the international market through business financial strategies and decisions to reach business performance.

\subsection{Effects of Business Strategies on International Market Entry}

Being in a competitive business environment encourages entrepreneurs to not fully rely on conventional business strategies. Likewise, SME owners need more flexibility in formulating business strategies that are different from their competitors to remain competitive. SMEs need to expand their business operations to serve non-local markets when local markets are saturated and the business condition is no longer conducive. In this respect, internationalization refers to a process to enhance a firm's involvement in the international market (Bell, Crick, \& Young, 2004). SMEs that exhibit a global business ability and an orientation towards non-regional business expansion can be classified as early adopters of internationalization (Knight \& Cavusgil, 2004). SMEs with unique and heterogeneous products have greater potentials to exploit existing market niches. The formulation of appropriate business strategies helps SMEs develop clear business missions and analyze both internal and external environments (Augier \& Teece, 2009; Makadok \& Ross, 2013). SMEs that seek to position themselves in a global perspective need to have strategies to strengthen their positions, reach non-local markets, and even maintain business networks with other partners for cost efficiency.

Hypothesis 1: Business strategies positively affect international market entry.

\subsection{Effects of Business Strategies on Financial Decisions}

The implementation of policies is a consequence of previously formulated strategies. In the business world, business strategies guide entrepreneurs or managers in their decision-making processes, such as financial decisions. SMEs' poor financial management exacerbates their development and growth (Jindrichovska, 2013; Timmons \& Spinelli, 2004). SMEs' business financial health is the main factor of SMEs' success in coping with financial constraints (López Salazar, Contreras Soto, \& Espinosa Mosqueda, 2012). SMEs ideally allocate their limited resources efficiently and effectively to ensure their survivability and to generate profits. Thus, SMEs' strategies will determine their competitiveness. Consequently, entrepreneurs need to translate their financial decisions carefully through entrepreneurship-oriented financing and investment activities. Entrepreneurs need to be risk-taking, proactive, and innovative in their financial decisions.

Hypothesis 2: Business strategies positively affect financial decisions. 


\subsection{Moderating Effects of Financing Access}

SMEs need more resources when serving the global market with a wider market reach than when only serving local markets. Firms' financial constraints will affect their investments (Bond, Elston, Mairesse, \& Mulkay, 2003), especially for small and young firms that are sensitive to tangible assets as collateral (Almeida \& Campello, 2007). By using Heckscher-Ohlin and Ricardo's model, Stiebale (2011) explained that firms manage to reach expected levels of capital to achieve a competitive advantage through an economy of scale only when they have low financial constraints. Strong capital assistance facilitates entrepreneurs to be more independent and flexible when formulating their strategies. Through formulated business strategies, entrepreneurs perceive that they can control all business activities that are connected with the supply chain. This perception affects entrepreneurship-oriented financial decisions, particularly in financing, investments, and profit allocation. However, low financing access likely weakens the impact of business strategies on SMEs' financial decisions.

Hypothesis 3: Financing access moderates the effects of business strategies on financial decisions.

\subsection{Effects of Financial Decisions on International Market Entry}

Previous studies highlight the importance of firms' financial management for international trade. Liquidity plays an important role in facilitating international trade through trade credits, debt guarantees, or subsidized bank loans (Stiebale, 2011). Likewise, SMEs need to enhance their physical and non-physical investments to facilitate internationalization activities. Financial decisions that fail to anticipate business growth will inhibit the implementation of these strategies. In this respect, the financial aspect is an important issue for SMEs that enter the international market. A well-established financial system is considered a prerequisite to achieve optimal capital levels and to accelerate the industrial economy of scale (Farkas, 2016). George, Wiklund, and Zahra (2005) indicated that SMEs' ownership structure affects their willingness to take risks and expand the business internationalization scale and scope. The entrepreneurship spirit of small entrepreneurs inspires each decision and behavior, and eventually the willingness to take external financing risks will stimulate investment activities and more aggressive and innovative business expansion.

Hypothesis 4: Financial decisions positively affect international market entry.

\subsection{Effects of Business Strategies on SMEs' Performance}

The methods or strategies to achieve objectives likely affect the target achievement rate, including in business activities. In SMEs, in which owners-managers are fully in control, the target achievement is primarily affected by owners (Blackburn, Hart, \& Wainwright, 2013). However, in corporate firms that clearly separate ownership and management, their strategy formulations to achieve business performance are different from SMEs. Performance improves when SMEs manage to control their business activities that are closely related to their supply chains. Entrepreneurs' products are business strategies as a medium to achieve their business objectives. Storey (1994) explains that SME growth is the intersection or combination of three components, namely the entrepreneur, strategy, and firm. Thus, it takes reliable human resources with sufficient capacities and capabilities to manage business growth well through appropriate strategy implementation.

Hypothesis 5: Business strategies positively affect SMEs' performance.

\subsection{Effect of Financial Decisions on SMEs' Performance}

A component of corporate management is financial management. SMEs' financial management is the product of entrepreneurs' financial decisions. SMEs' financial decisions are not different from corporate firms' decisions that consist of financing, investing, and profit utilization decisions (Coleman, 2004). However, SMEs need to adjust the implementation of their financial decisions because of greater information asymmetry and agency problems than larger firms (Pettit \& Singer, 1985). Firms' abilities to ensure capital adequacy to support their operations (Gul et al., 2013), and to allocate funds to innovative investments through R\&D (Chiao, Yang, \& Yu, 2006) likely improve their business performance. SME owners also often choose the bootstrapping strategy to reduce their dependence on external financing (Ebben, 2009; Vanacker \& Sels, 2009). The resource-based stream (Barney \& Arikan, 2001) arguably underlies the internationalization theory as indicated by the fact that firms with unique, valuable, and inimitable resources will transfer their resources, including financial ones, to the international market to achieve higher profits. Consequently, entrepreneurs need to have skills to access external resources, whether formally or informally, as business capital. In this respect, capital is the antecedent of SMEs' value creation.

Hypothesis 6: Financial decisions positively affect SMEs' performance. 


\subsection{Effects of International Market Entry on SMEs' Performance}

Indonesia is an archipelago country with various socio-cultural backgrounds and rich natural resources. Its geographic and natural conditions are potential inputs for firms' various and innovative products. Indonesian SMEs' varied and unique products have significant potential to enter export markets. Exporting enables SMEs to grow and generate greater profits because of the wider market (H. S. Rasheed, 2005). When entering the global market, SMEs will have broader access to acquire new customers that potentially increase their long-term revenue and growth. Firms can materialize the potentials into business performance if they strengthen their competitiveness by improving their product quality to meet customers' demands. Hollender, Zapkau, and Schwens (2017) observed that SMEs' international experience and product adaptation contribute to the choice of internationalization strategy and business performance (sales volume, sales growth, profits, market share, and marketing). SMEs that have a previous global business transaction history will be better able to implement an internationalization strategy because of knowledge transplantation (Love, Roper, \& Zhou, 2016) and to generate higher business performance. Firms commit to devoting their resources to international operations when they have sufficient experience to reduce business uncertainty (Hilmersson \& Johanson, 2016).

Hypothesis 7: International market entry positively affects SMEs' performance.

\subsection{Mediation of International Market Entry Towards the Influence of Business Strategies on SMEs' Performance}

SMEs' efforts to enter the global market do not directly improve their performance (Camisón \& Villar - López, 2010; Zhou, Wu, \& Luo, 2007). In this respect, several factors likely mediate the relation, including SMEs' business strategies. The business strategy formulation helps entrepreneurs perceive that they manage to control all business activities that are related to the supply chain (Stiebale, 2011). Besides that, efforts to intensify new product offerings in the market proactively also contribute to performance improvement (Hagen, Zucchella, Cerchiello, \& De Giovanni, 2012). SMEs' ability to survive in the global market is also closely related to their cooperation strategies with other parties for production cost efficiency (Ellis, 2000; Zhou et al., 2007) through knowledge about international market opportunities, experience sharing, solidarity, and referral trust. Thus, the implementation of a combined business strategy will optimize SMEs' business performance.

Hypothesis 8: International market entry mediates the effects of business strategies on SMEs' performance.

\subsection{Mediation of International Market Entry Towards the Influence of Financial Decisions on SMEs' Performance}

Entrepreneurs' complex managerial decision making, such as marketing, financial choices, and operational decisions, does not automatically improve performance (Shehu et al., 2013). In this case, SMEs need to match their managerial decisions with their strategies to survive in the international market. While previous investing and financing activities only focused on domestic markets, SMEs now need to develop financial activities that support their internationalization. For example, they can increase their investments through aggressive advertising (Chiao, Yang, \& Yu, 2006) and the utilization of technology (Todd \& Javalgi, 2007). Meanwhile, they can revise their financing through the ownership structure. The involvement of external owners arguably changes SME owners' behaviors to focus on the scale of expansion and the scale of internationalization. The scale explains the extent that SMEs rely on the international market in their marketing, production, and R\&D activities; while the scope refers to the international reach to penetrate other countries in SMEs' business activities (George et al., 2005).

Hypothesis 9: International market entry mediates the effects of financial decisions on SMEs' performance.

\section{Research Method}

\subsection{Population and Sample}

The population was SMEs of which products or services had reached non-regional markets or were even exported and were located in the city of Salatiga, Central Java, and the city of Medan, North Sumatera. Salatiga has a strategic location because it connects the main route of Yogyakarta, Solo, and Semarang (Joglosemar). Meanwhile, Medan actively and productively promotes SMEs and cooperatives. These factors help the economies of both cities develop significantly because their local product market reaches are potentially expandable. The sample in this research was SMEs in the creative industry category which have a strategic potential to penetrate the international market. SMEs have product diversity and quality that are able to compete with products from other countries. Indonesia is an archipelago nation which consists of various ethnic groups and cultures, in which this cultural diversity is reflected in the local products produced with unique and special characteristics. 
Table 1. Number of SMEs in Salatiga and Medan

\begin{tabular}{clc}
\hline No. & \multicolumn{1}{c}{ Location } & Population \\
\hline 1. & SMEs in Salatiga & 799 \\
2. & SMEs in Medan & 300 \\
\hline & Total & 1,099 \\
\hline
\end{tabular}

Source: Center for Micro and Small Enterprise Dynamics (2019) and the Provincial Office of Cooperatives and MSMEs, North Sumatra (2019)

Table 1 displays the number of SMEs in Salatiga and Medan. Only a small portion of SMEs have penetrated non-regional areas relative to the total business units. Based on the previous criteria, 250 SMEs were selected from various sectors. In particular, the criteria were: (a) the SME was at least two years old as a proxy of business continuity, and (b) the SME operated in a creative industry and intended to enter the international market.

\subsection{Variables and Variable Measurement}

The research model consisted of five latent exogenous and endogenous variables, namely: business strategy, financial decision, international market entry, SME performance, and financing access. Each variable was measured by several question items that were developed from previous literature (Table 2). Excerpts of several references were included in Table 2 to represent the indicators in measuring the latent variables in the empirical model. This was adjusted with the condition of SMEs in Indonesia, so that several indicators were modified to reduce the number of question items in the questionnaire. In particular, the business strategy was modified from Wingwon (2015), the financial decision was modified from Lopez Salazar et al. (2012), the international market entry was modified from Ekeledo and Sivakumar (2004), the SME performance was modified from Torugsa, O'Donohue, and Hecker (2012), and the financing access was modified from Duan, Han, and Yang (2009).

Table 2. Research variables and their measurements

\begin{tabular}{clll}
\hline No. & \multicolumn{1}{c}{ Variable } & & \multicolumn{1}{c}{ Indicator } \\
\hline 1 & Financial Access & - & Ease \\
& & - & Amount of capital \\
\hline 2 & Business Strategy & - & Integrative \\
& & - & Intensive \\
& & - & Diversification \\
& & - & Other \\
\hline 3 & Financial Decision & - & Investment Decision \\
& & - & Financing Decision \\
\hline 4 & International Market & - & Internationalization Readiness \\
& Entry & - & International Cooperation \\
\hline 5 & SME Performance & - & Financial Performance \\
& & - & Market Performance \\
\hline
\end{tabular}

Consistent with the 5-scale Likert category, the respondents' perceptions of these questions were measured by a scale of 1 to 5 (1: very low; 2: low; 3: moderate; 4: high; 5: very high).

\subsection{Analysis Technique}

The Partial Least Squares (PLS) - Structural Equation Modelling (SEM) method was utilized by applying WarpPLS version 6.0 to analyze the data. According to Latan and Ghozali (2016), PLS-SEM offers the following advantages: 1) it can test social research with research models that rely on latent variables with high complexity; 2) it does not require normally distributed data and it can handle all measurement scales (nominal, ordinal, interval, and ratio); and 3 ) it has been tested with a clear basic design and concept that have been introduced for more than 30 years.

The model conceptualization of this study used the latent variables in a reflective form or commonly labeled as mode A. The mode is the indicator that manifests towards constructs (Latan \& Ghozali, 2016). The PLS-SEM determines the algorithm analysis method (outer model and inner model). In this study, the outer model used mode A because the latent variables were in a reflective form. Meanwhile, the inner model used the linear choice because the hypotheses were in a structural form that had a linear relationship. Furthermore, the research relied on a stable resampling method because the method produced the most stable path coefficient value (Sholihin \& Ratmono, 2013). 


\section{Discussion}

\subsection{Respondents' and SMEs' Profiles}

Table 3 below presents the respondents' profiles as the sample of this study.

Table 3. Respondents' characteristics

\begin{tabular}{|c|c|c|}
\hline Sex & & \\
\hline Male & & 130 \\
\hline Female & & 120 \\
\hline \multicolumn{3}{|l|}{ Experience } \\
\hline Min & & 2 \\
\hline Max & & 59 \\
\hline Average & & 9 \\
\hline \multicolumn{3}{|l|}{ Education Level } \\
\hline Junior high school & 18 & \\
\hline Senior high school & 92 & \\
\hline Diploma & 27 & \\
\hline Bachelor & 77 & \\
\hline Master & 19 & \\
\hline Other & 17 & \\
\hline
\end{tabular}

Source: Processed primary data (2019)

In general, most respondents were male (52\%), and the rest were female (48\%). The longest business experience was 59 years, indicating that the business was inherited from the previous generation. Also, the average business age was nine years, implying that SMEs survived the critical phase because they still existed after five years of operation (Barkham, Gudgin, \& Hart, 2002). Furthermore, most respondents had senior high school degrees (37\%) followed by bachelor's degrees $(30 \%)$. The respondents had varied education levels largely because of sociological, economic, and educational infrastructure differences.

The following table explains SMEs' profiles of the business type, business capital, and monthly sales. In particular, the culinary sector dominates the business type (37\%), followed by the other sectors (22\%). On average, the respondents have a high level of capital of Rp 121 million, while the average monthly sales are above Rp 5 million $(50 \%)$.

Table 4. Business characteristics

\begin{tabular}{lr}
\hline Business Type & \\
\hline Culinary & 94 \\
Handicrafts & 38 \\
Fashion & 38 \\
Agrobusiness & 10 \\
Automotive & 15 \\
Other & 55 \\
\hline Business Capital (IDR) & \\
\hline Min & 200,000 \\
\hline Max & \\
\hline Average & 27 \\
\hline Monthly Sales (IDR) & $900,000,000$ \\
\hline$<1$ million & $121,328,251$ \\
\hline 1 - 5 million & \\
$>5$ million & \\
\hline
\end{tabular}

Source: Processed primary data (2019) 


\subsection{Model Test and Results}

The analysis to test the research model consisted of two stages, namely the measurement model assessment, and the structural model assessment. The measurement model assessment aimed to assess the reliability and validity of the indicators that formed the latent variables. The following table shows the results of the reliability test of the indicators that formed all the variables.

Table 5. Loading factor values of the indicators of the research variables

\begin{tabular}{|c|c|c|}
\hline Variable & Indicator & Loading Factor \\
\hline \multirow{6}{*}{$\begin{array}{l}\text { Financing Access } \\
\text { (FA) }\end{array}$} & FA1 & 0.901 \\
\hline & FA2 & 0.896 \\
\hline & FA3 & 0.843 \\
\hline & FA4 & 0.473 \\
\hline & FA5 & 0.634 \\
\hline & BS1 & 0.799 \\
\hline \multirow{6}{*}{$\begin{array}{l}\text { Business Strategy } \\
\text { (BS) }\end{array}$} & $\mathrm{BS} 2$ & 0.792 \\
\hline & $\mathrm{BS} 3$ & 0.793 \\
\hline & BS4 & 0.671 \\
\hline & BS5 & 0.659 \\
\hline & BS6 & 0.811 \\
\hline & BS7 & 0.788 \\
\hline \multirow{7}{*}{$\begin{array}{l}\text { Financial Decision } \\
\text { (FD) }\end{array}$} & FD1 & 0.684 \\
\hline & FD2 & 0.726 \\
\hline & FD3 & 0.44 \\
\hline & FD4 & 0.6 \\
\hline & FD5 & 0.729 \\
\hline & FD6 & 0.752 \\
\hline & FD7 & 0.646 \\
\hline \multirow{7}{*}{$\begin{array}{l}\text { International Market } \\
\text { Entry } \\
\text { (EIM) }\end{array}$} & EIM1 & 0.761 \\
\hline & EIM2 & 0.782 \\
\hline & EIM3 & 0.859 \\
\hline & EIM4 & 0.75 \\
\hline & EIM5 & 0.696 \\
\hline & EIM6 & 0.758 \\
\hline & EIM7 & 0.716 \\
\hline \multirow{5}{*}{$\begin{array}{l}\text { SMEs' Performance } \\
\text { (SP) }\end{array}$} & MP1 & 0.852 \\
\hline & MP2 & 0.884 \\
\hline & MP3 & 0.897 \\
\hline & MP4 & 0.906 \\
\hline & MP5 & 0.884 \\
\hline
\end{tabular}

Source: Processed primary data (2019)

Determining reliable indicators is necessary to assess the loading factor that has to be greater than 0.7. In addition, to meet the convergent validity criteria, the indicators have to produce an AVE value $>5$, and a composite reliability value >0.7. Besides that, to meet the discriminant validity criteria, the comparison of the square root of the AVE for each variable must be greater than the correlation between variables (Latan \& Ghozali, 2016). Table 4 reveals that 
several indicators were left out of the measurement model, namely: FA4, FA5, BS4, BS5, FD1, FD3, FD4, FD7, and EIM5. Table 6 below displays the reliability and validity analysis with details such as the loading factor value, composite reliability value, and AVE of the variables.

Table 6. Loading factor value, composite reliability, and average variance extract

\begin{tabular}{ccccc}
\hline \multirow{2}{*}{ Variable } & Indicator & Indicator Reliability & $\begin{array}{c}\text { Internal Consistency } \\
\text { Reliability }\end{array}$ & Convergent Validity \\
\cline { 2 - 5 } Financing Access & Loading Factor & Composite Reliability & AVE \\
\cline { 2 - 5 } & FA1 & 0.901 & & 0.832 \\
& FA2 & 0.896 & 0.937 & \\
& FA3 & 0.843 & & 0.668 \\
Business Strategy & BS1 & 0.799 & & \\
& BS2 & 0.792 & & \\
& BS3 & 0.793 & & \\
& BS6 & 0.811 & & \\
Financial & BS7 & 0.788 & & \\
Decision & FD2 & 0.726 & & \\
& FD5 & 0.729 & & \\
& FD6 & 0.752 & & \\
International & EIM1 & 0.761 & & \\
Market Entry & EIM2 & 0.782 & & \\
& EIM3 & 0.859 & & \\
& EIM4 & 0.75 & & \\
& EIM6 & 0.758 & & \\
& EIM7 & 0.716 & & \\
\hline \multirow{5}{*}{ SME Performance } & MP1 & 0.852 & & \\
& MP2 & 0.884 & & \\
& MP3 & 0.897 & & \\
& MP4 & 0.906 & & \\
& MP5 & 0.884 & & \\
\hline
\end{tabular}

Source: Processed primary data (2019)

Table 6 suggests that all the indicators of the items that form the Financing Access, Business Strategy, Financial Decision, International Market Entry, and SME Performance variables are valid because they have loading factor values greater than 0.4 . The results imply that all indicators have good indicator reliability. Furthermore, the findings also indicate that the AVE values of each variable are very good (>0.5) and meet the convergent validity criteria. In a similar vein, the composite reliability value of each variable is very good $(>0.7)$ and meets the internal consistency reliability.

Table 7 below illustrates the comparison between the square root of AVE and the correlation between constructs:

Table 7. Square root of the AVE and the correlation between variables

\begin{tabular}{lcccccc}
\hline \multicolumn{1}{c}{ Construct } & $\begin{array}{c}\text { Square Root of } \\
\text { the AVE }\end{array}$ & FA & BS & FD & EIM & MP \\
\hline Financing Access & 0.912 & 1 & 0.636 & 0.375 & 0.535 & 0.725 \\
Business Strategy & 0.817 & 0.636 & 1 & 0.527 & 0.606 & 0.771 \\
Financial Decision & 0.807 & 0.375 & 0.527 & 1 & 0.429 & 0.466 \\
International Market Entry & 0.79 & 0.535 & 0.606 & 0.429 & 1 & 0.66 \\
SME Performance & 0.885 & 0.725 & 0.771 & 0.466 & 0.66 & 1 \\
\hline
\end{tabular}

Source: Processed primary data (2019) 
The results demonstrate that the square root of the AVE for each variable is greater than the correlation between variables, which implies good discriminant validity. The structural model assessment was then implemented. The test aimed to predict the relationship between variables by analyzing the extent of variance that could be explained and the significance of the p-value (Latan \& Ghozali, 2016). Thus, the structural model test could answer the seven hypotheses. Before evaluating the relationships between variables, the goodness of fit of the research model was evaluated as displayed in Table 8.

Table 8. Goodness of Fit of the structural model

\begin{tabular}{|c|c|c|c|}
\hline Criteria & Rule of Thumb & Parameter & Conclusion \\
\hline Average path coefficient (APC) & Acceptable $\mathrm{P}<0.05$ & $0.304 /$ P-value $<0.01$ & accepted \\
\hline Average R-squared (ARS) & Acceptable $\mathrm{P}<0.05$ & $0.439 / \mathrm{P}$-value $<0.01$ & accepted \\
\hline $\begin{array}{l}\text { Average adjusted R-squared } \\
\text { (AARS) }\end{array}$ & Acceptable $\mathrm{P}<0.05$ & $0.434 / \mathrm{P}$-value $<0.01$ & accepted \\
\hline Average block VIF (AVIF) & $\begin{array}{c}\text { Acceptable if } \leq 5 \text {, ideally } \leq \\
3.3\end{array}$ & 1.403 & accepted \\
\hline $\begin{array}{l}\text { Average full collinearity VIF } \\
\text { (AFVIF) }\end{array}$ & $\begin{array}{c}\text { Acceptable if } \leq 5 \text {, ideally } \leq \\
3.3\end{array}$ & 2.193 & accepted \\
\hline Tenenhaus GoF (GoF) & $\begin{array}{c}\text { Small } \geq \\
\text { large } \geq 0.1, \text { medium } \geq 0.25,\end{array}$ & 0.545 & accepted \\
\hline Sympson's paradox ratio (SPR) & $\begin{aligned} \text { Acceptable if } & \geq 0.7, \text { ideally } \\
& =1\end{aligned}$ & 1 & accepted \\
\hline $\begin{array}{l}\text { R-squared contribution ratio } \\
\text { (RSCR) }\end{array}$ & $\begin{aligned} \text { Acceptable if } & \geq 0.9, \text { ideally } \\
& =1\end{aligned}$ & 1 & accepted \\
\hline Statistical suppression ratio (SSR) & Acceptable if $\geq 0.7$ & 1 & accepted \\
\hline
\end{tabular}

Source: Processed primary data (2019)

Table 8 suggests that the research model has a very good fit as indicated by the p-values of APC, ARS, and AAR $<0.05$ with the APC value $=0.304$, ARS value $=0.439$, and AARS value $=0.434$. Likewise, the AVIF and AFVIF values are <3.3, implying that there is no multicollinearity problem between the indicators and between the exogenous variables. The findings also indicate that $\mathrm{GoF}$ is $0.545>0.36$, which suggests that the model fit is very good. Lastly, the values of SPR, RSCR, and SSR are $1>0.7$, implying no causality problem in the model (Latan \& Ghozali, 2016).

Next, Table 9 and Figure 1 illustrate the results of the estimation of the relationships between constructs and the degree of the variance.

Table 9. Estimation results of the relationships between variables

\begin{tabular}{lccc}
\hline \multicolumn{1}{c}{ Description Path } & Path Coefficient & $\mathbf{R}^{\mathbf{2}}$ & $\mathbf{Q}^{\mathbf{2}}$ \\
\hline Business Strategy $\rightarrow$ International Market Entry & $0.527^{* * *}$ & 0.384 & 0.387 \\
Financial Decision $\rightarrow$ International Market Entry & $0.151^{* * *}$ & & \\
Financing Access * Business Strategy $\rightarrow$ Financial & -0.024 & 0.278 & 0.281 \\
Decision & $0.52^{* * *}$ & & \\
Business Strategy $\rightarrow$ Financial Decision & $0.571^{* * *}$ & 0.654 & 0.654 \\
Business Strategy $\rightarrow$ SME Performance & $0.297^{* * *}$ & & \\
International Market Entry $\rightarrow$ SME Performance & 0.038 & & \\
Financial Decision $\rightarrow$ SME Performance & &
\end{tabular}

Source: Processed primary data (2019) 
Table 9 shows that the $R$-squared $\left(R^{2}\right)$ value of the variation that affects international market entry is 0.38 . The figure indicates that the effects of the variation of Business Strategy and Financial Decision on the variation of International Market Entry are only 38\%, while the rest (62\%) is affected by other variables. Meanwhile, the variation that affects Financial Decision is 0.28, implying that the effects of the variation of Business Strategy and the interaction between Financing Access and Business Strategy on Financial Decision are $28 \%$, and the rest $(72 \%)$ is affected by other variables. Next, the variation that affects SME Performance is 0.65 . The result implies that the effects of the variation of Business Strategy, International Market Entry, and Financial Decision on the variation of SME Performance are $65 \%$, while the rest $(35 \%)$ is affected by other variables. The $\mathrm{R}$-squared $\left(\mathrm{R}^{2}\right)$ value of the variation that affects International Market Entry falls into the moderate category $\left(0.25 \leq R^{2} \leq 0.45\right)$. The $R$-squared $\left(R^{2}\right)$ value of the variation that affects Financial Decision is within the moderate category $\left(0.25 \leq R^{2} \leq 0.45\right)$. Meanwhile, the R-squared $\left(R^{2}\right)$ value of the variation that affects SME Performance falls into the strong category ( $\left.R 2 \geq 0.45\right)$. Next, the Q-squared value of International Market Entry, Financial Decision, and SME Performance are above 0, implying that the model has predictive relevance (Latan \& Ghozali, 2016).

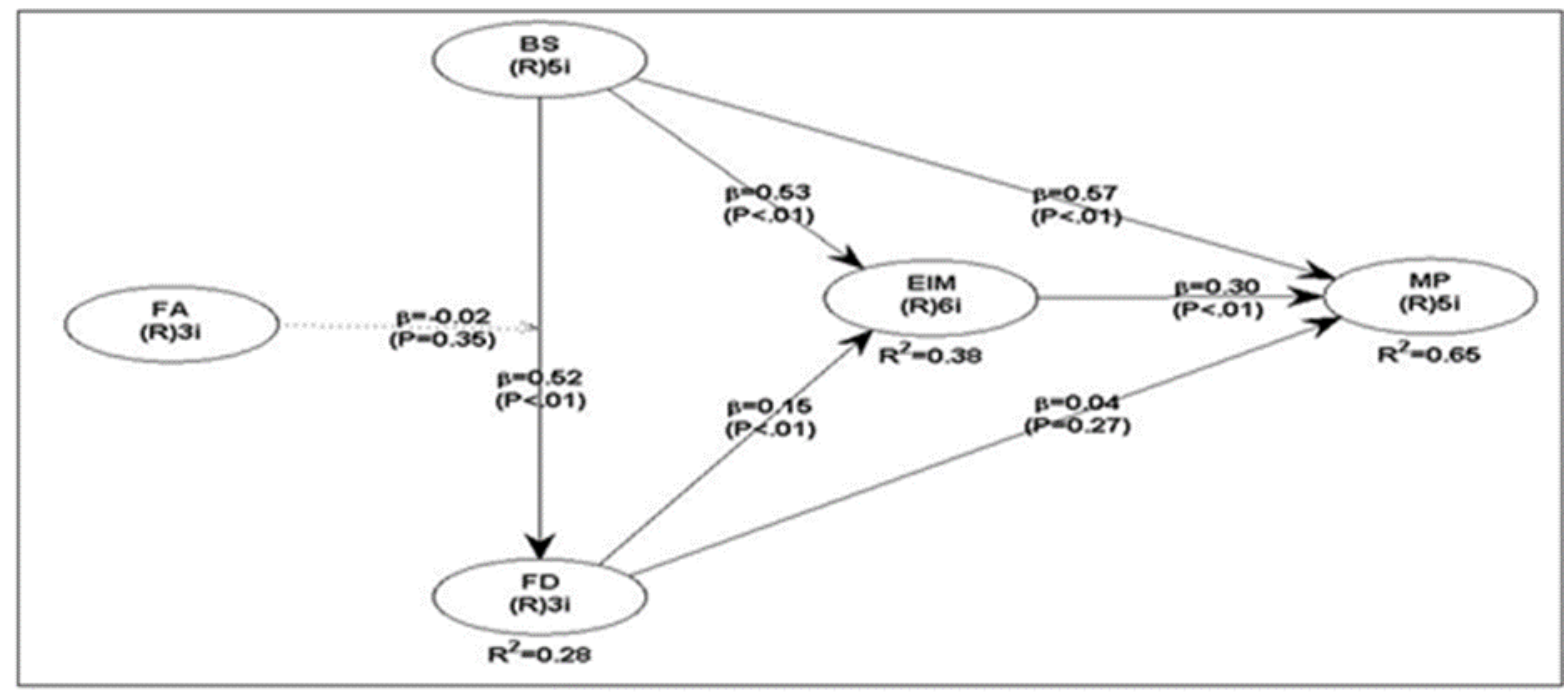

Figure 1. The estimation results of the relationship between variables

The outputs in Table 9 and Figure 2 were used to test the research hypotheses. Hypothesis 1 postulated that the Business Strategy positively affects International Market Entry. The results show that the Business Strategy variable positively affects International Market Entry (p-value $<0.01$ with a path coefficient value of 0.53 ) and thus supports hypothesis 1. Consequently, a higher Business Strategy increases International Market Entry.

Hypothesis 2 postulated that Business Strategy positively affects Financial Decision. The findings indicate that Business Strategy positively affects Financial Decision ( $p$-value $<0.01$ and a path coefficient value of 0.52 ) and thus supports hypothesis 2. The results demonstrate that higher Business Strategy increases Financial Decision.

Hypothesis 3 proposed that Financing Access moderates the effect of Business Strategy on Financial Decision. However, this test suggested there was no moderating role of Financing Access in the relationship between Business Strategy on Financial Decision (p-value $>0.1$ and a path coefficient value of -0.22). Thus, hypothesis 3 is rejected.

Hypothesis 4 suggested that Financial Decision positively affects International Market Entry. The results demonstrate that the Financial Decision variable positively affects International Market Entry (p-value $<0.01$ and a path coefficient value of 0.15 ), and this study supports hypothesis 4 . The findings show that a higher Financial Decision increases International Market Entry.

Hypothesis 5 put forth that Business Strategy positively affects SME Performance. The outputs indicate that the Business Strategy variable positively affects SME Performance ( $p$-value $<0.01$ and a path coefficient value of 0.571 ). The results support hypothesis 5. Thus, an increased Business Strategy enhances SME Performance. 
Hypothesis 6 claimed that Financial Decision positively affects SME Performance. The outputs suggest that the Financial Decision variable insignificantly affects SME Performance (p-value $>0.1$ and a path coefficient value of 0.04). The findings reject hypothesis 6 and imply no effect of Financial Decision on SME Performance.

Hypothesis 7 suggested that International Market Entry positively affects SME Performance. The results show that the International Market Entry variable positively affects SME Performance (p-value $<0.01$ and a path coefficient value of 0.297), and thus the findings support hypothesis 7. Consequently, a greater International Market Entry increases SME Performance.

Hypothesis 8 predicted that International Market Entry mediates the impact of Business Strategy on SME Performance. The findings demonstrate that International Market Entry significantly mediates the path (a path coefficient value of 0.045), and hypothesis 8 is supported. Thus, International Market Entry acts as a partial mediation of the effect of Business Strategy on SME Performance, because the direct effect of both variables is significant.

Hypothesis 9 projected that International Market Entry mediates the impact of Financial Decision on SME Performance. The results show that International Market Entry does not mediate the path (a path coefficient value of $0.19)$, and hypothesis 9 is not supported.

The structural model exhibits two indirect relationships, namely: BS>EIM $>$ MP and FD>EIM>MP. Table 10 illustrates the indirect relationship between both paths.

Table 10. Indirect effects

\begin{tabular}{lccc}
\hline Description Path & $\begin{array}{c}\text { Path } \\
\text { Coefficient }\end{array}$ & \multicolumn{2}{c}{ Finding } \\
\hline $\begin{array}{l}\text { Business Strategy>International Market Entry> } \\
\text { SME Performance }\end{array}$ & $0.19 * *$ & Significantly positive & Mediation \\
$\begin{array}{l}\text { Financial Decision>International Market Entry> } \\
\text { SME Performance }\end{array}$ & 0.045 & Insignificantly positive & No mediation \\
\hline
\end{tabular}

***,**,* denotes significance levels at $0.01,0.05$, and 0.1 , respectively

Source: Processed primary data (2019)

Table 10 suggests that International Market Entry mediates the effect of Business Strategy on SME Performance (p-value $<0.05$ and a path coefficient value of 0.050). Meanwhile, International Market Entry does not mediate the impact of Financial Decision on MSME Performance.

\subsection{Determinants of International Market Entry}

In an entrepreneurial finance context, entrepreneurs play a vital role in devising strategies, in order that their businesses can grow and develop. This study demonstrates that the business strategy determines SMEs' increased involvement in international market entry. Appropriate business strategies motivate SMEs to identify their internal and external (global market) environments (Augier \& Teece, 2009; Makadok \& Ross, 2013). Intensive efforts for market expansion encourage SMEs to prepare international market entry. Furthermore, diversification of business strategies adds a wider market by not focusing only on increasingly saturated local markets but also integrating the international market as the target market.

Additionally, the study found that an appropriate financial decision is a determining factor of SMEs' success in selling their products to the international market. The results confirm previous studies, such as George et al. (2005); Stiebale (2011), and (Farkas, 2016), who concluded that SMEs need to have sound financial systems and strong liquidity to enter the international market. They need to support long-term investment decisions to enter the broader international market by having better financing sources. Possessing an efficient capital structure significantly helps SMEs invest in competitive products to survive in the international market.

\subsection{Determinants of Financial Decisions}

This analysis confirmed that financial decisions are positively affected by business strategies. Different from López Salazar et al. (2012), this study demonstrated no conformity between business strategies and financial decisions. Business strategies through intensive efforts, the integration of the target market, and product diversification motivate SMEs to manage their finances better. The choice of a business strategy requires efficient financial 
management both in searching for financing sources and allocating the funds into investments. Entrepreneurial finance will become a foundation for someone who will launch a business or is managing a business that is being run (Rogers \& Makonnen, 2014), because it involves financial planning and management activities.

Furthermore, this study also shows that financing access does not increase the effects of a business strategy on financial decisions. This study observed that appropriate business strategies will mitigate SMEs' financial constraints without specifically relying on external financing access (financially independent). Ease of financial access will understandably not play a significant role when SMEs can run their businesses professionally to beat out the competition.

\subsection{Determinants of SMEs' Performance}

The results confirm that business strategies positively affect SMEs' performance. SME owners hold full control over every business activity. Consequently, they need to execute every business opportunity immediately (Blackburn et al., 2013). Entrepreneurs' risk-taking behavior facilitates strategies that strengthen their product positions in markets despite probable future failures. Besides that, SME owners' ability to manage their firms' supply chain also positively affects their business performance. Being aware that their businesses have various limitations, it motivates entrepreneurs to develop business relationships with various parties to enhance the efficiency of production costs and marketing.

Financial decisions do not affect SMEs' performance. Coleman (2004) claimed that small firms' financial decisions are riskier than larger firms' financial decisions because of information asymmetry problem. Both problems tend to make SMEs' investment decisions unprofitable or feasible. Access to external financing sources also constrains SMEs' financing decisions that lead to financial inflexibility (Byoun, 2008). Consequently, SMEs' suboptimal financial decisions do not affect their business performance.

Financial activities in a company follow the company's lifecycle (Fraser, Bhaumik, \& Wright, 2015). When an SME enters the expansion phase, it will need greater financial support compared with in the introduction phase or the decline phase. Greater international market entry increases SMEs' performance. Business networks developed by SME owners to enter export markets positively affect their business performance (Lu \& Beamish, 2001). This sample mostly cooperated with local and international business partners to help them enter the international market. Business relations are further strengthened by good relationships with customers in the international market that create consumer satisfaction and loyalty.

Besides testing the direct relationships between several variables and SMEs' performance, this study also tested the mediating role of international market entry in two antecedent variables, namely business strategy and financial decision. International market entry acts as a partial mediation of the impact of a business strategy on an SME's performance. Thus, SMEs' performance will be more optimal when their business strategies increase their international market entry. Intensively implemented strategies will enhance the internationalization preparedness and international cooperation. These strategies will motivate entrepreneurs to act more aggressively, proactively, and competitively than their competitors who only play in local markets. Meanwhile, international market entry does not mediate the effects of financial decisions on SMEs' performance. SMEs' suboptimal financial decisions due to information asymmetry and agency conflicts directly weaken SMEs' export activities and performance. Entrepreneurs who focus more on routine operations through financing and investment decisions will not intensify their internationalization efforts. Thus, this factor does not significantly affect financial and marketing performance.

\section{Conclusions, Limitations, and Future Research Agenda}

A limited number of Indonesian SMEs engage in international trade due to both internal and external business constraints. These findings help to formulate strategies to stimulate SMEs' exports or internationalization that will optimize their performance. Also, the results document that business strategies and financial decisions are the determinants of an SME's international market entry. In addition, the business strategy and international market entry are important to enhance an SME's performance. Furthermore, international market entry optimizes the impact of the business strategy on an SME's performance.

This research can enrich studies about the entrepreneurial finance theory from the demand perspective (SME actors), where entrepreneurial activities cannot be separated from good financial management (investment and financing decisions). This intersection between entrepreneurial and finance activities can stimulate good SME performance. The manager-owner characteristic in SMEs creates uniqueness in determining the business strategies and financial decisions that are produced by SMEs. Moreover, there are a number of external factors that influence SME entrepreneurial behavior in decision making, such as environmental and social factors (R. Rasheed \& Siddiqui, 2019). 
Differences in characteristics between corporate companies and small enterprises result in different decisions made by each business actor.

This study has several limitations, such as the low variation of the effects of international market entry ( $\mathrm{R}^{2}$ of $\left.38 \%\right)$. The figure suggests the need to accommodate several new variables in the model, because this study shows that international market entry increases an SME's performance. It is then suggested that future research should explore the behavioral aspect of SME owners such as commitment, managerial ability, and perceived internal constraints in enhancing export intention (Martineau \& Pastoriza, 2016). These research agendas are important because owner-managers dominate SMEs and affect business decisions.

\section{Acknowledgements}

This research was funded by the Ministry of Technology and Higher Education Research of the Republic of Indonesia, in the form of research grants for university collaboration.

\section{References}

Almeida, H., \& Campello, M. (2007). Financial constraints, asset tangibility, and corporate investment. The Review of Financial Studies, 20(5), 1429-1460.

Argerich, J., Hormiga, E., \& Valls-Pasola, J. (2013). Financial Services Support for Entrepreneurial Projects: Key Issues in the Business Angels Investment Decision Process. Service Industries Journal, 33(9/10), 806-819. doi:10.1080/02642069.2013.719891

Augier, M., \& Teece, D. J. (2009). Dynamic capabilities and the role of managers in business strategy and economic performance. Organization Science, 20(2), 410-421.

Barkham, R., Gudgin, G., \& Hart, M. (2002). Determinants of small firm growth: An inter-regional study in the United Kingdom 1986-90 (Vol. 12). London: Psychology Press.

Bell, J., Crick, D., \& Young, S. (2004). Small firm internationalization and business strategy: an exploratory study of 'knowledge-intensive'and 'traditional'manufacturing firms in the UK. International Small Business Journal, 22(1), 23-56.

Bianchi, C., \& Wickramasekera, R. (2016). Antecedents of SME export intensity in a Latin American Market. Journal of Business Research, 69(10), 4368-4376.

Blackburn, R. A., Hart, M., \& Wainwright, T. (2013). Small business performance: business, strategy and owner-manager characteristics. Journal of Small Business and Enterprise Development, 20(1), 8-27.

Bond, S., Elston, J. A., Mairesse, J., \& Mulkay, B. (2003). Financial factors and investment in Belgium, France, Germany, and the United Kingdom: A comparison using company panel data. Review of Economics and statistics, 85(1), 153-165.

Briozzo, A., \& Vigier, H. (2009). A demand-side approach to SMES'capital structure: evidence from Argentina. Journal of Business and Entrepreneurship, 21(1), 30.

Brouthers, K. D., \& Hennart, J.-F. (2007). Boundaries of the firm: Insights from international entry mode research. Journal of Management, 33(3), 395-425.

Byoun, S. (2008). How and when do firms adjust their capital structures toward targets?. The Journal Of Finance, 63(6), 3069-3096.

Cadogan, J. W., Diamantopoulos, A., \& Siguaw, J. A. (2002). Export market-oriented activities: their antecedents and performance consequences. Journal of International Business Studies, 33(3), 615-626.

Camisón, C., \& Villar-López, A. (2010). Effect of SMEs' international experience on foreign intensity and economic performance: The mediating role of internationally exploitable assets and competitive strategy. Journal of Small Business Management, 48(2), 116-151.

Chemmanur, T. J., \& Fulghieri, P. (2014). Entrepreneurial Finance and Innovation: An Introduction and Agenda for Future Research. Review of Financial Studies, 27(1), 1-19. https://doi.org/10.1093/rfs/hht063

Chiao, Y.-C., Yang, K.-P., \& Yu, C.-M. J. (2006). Performance, internationalization, and firm-specific advantages of SMEs in a newly-industrialized economy. Small Business Economics, 26(5), 475-492.

Coleman, S. (2004). Variations on A Theme: Teaching Entrepreneurial finance. Journal of Entrepreneurship Education, 7, 73-81. 
Ellis, P. (2000). Social ties and foreign market entry. Journal of International Business Studies, 31(3), 443-469.

Farkas, G. (2016). The effects of strategic orientations and perceived environment on firm performance. Journal of Competitiveness, 8(1), 55-65.

Fernández, Z., \& Nieto, M. J. (2006). Impact of ownership on the international involvement of SMEs. Journal of International Business Studies, 37(3), 340-351.

Fraser, S., Bhaumik, S. K., \& Wright, M. (2015). What do we know about entrepreneurial finance and its relationship with growth?. International Small Business Journal, 33(1), 70-88.

George, G., Wiklund, J., \& Zahra, S. A. (2005). Ownership and the internationalization of small firms. Journal of Management, 31(2), 210-233.

Hagen, B., Zucchella, A., Cerchiello, P., \& De Giovanni, N. (2012). International strategy and performance - Clustering strategic types of SMEs. International Business Review, 21(3), 369-382.

Hilmersson, M., \& Johanson, M. (2016). Speed of SME internationalization and performance. Management International Review, 56(1), 67-94.

Hollender, L., Zapkau, F. B., \& Schwens, C. (2017). SME foreign market entry mode choice and foreign venture performance: The moderating effect of international experience and product adaptation. International Business Review, 26(2), 250-263.

Jindrichovska, I. (2013). Financial management in SMEs. European Research Studies Journal, 16(4), 79-96.

Kerr, W. R., Lerner, J., \& Schoar, A. (2014). The Consequences of Entrepreneurial Finance: Evidence from Angel Financings. Review of Financial Studies, 27(1), 20-55.

Knight, G. A. (2001). Entrepreneurship and strategy in the international SME. Journal of International Management, 7(3), 155-171.

Knight, G. A., \& Cavusgil, S. T. (2004). Innovation, organizational capabilities, and the born-global firm. Journal of International Business Studies, 35(2), 124-141.

Kontinen, T., \& Ojala, A. (2011). Network ties in the international opportunity recognition of family SMEs. International Business Review, 20(4), 440-453.

Latan, H., \& Ghozali, I. (2016). Partial Least Square Konsep, Metode dan Aplikasi Menggunakan WarpPLS 5.0. Semarang: Badan Penerbit Universitas Diponegoro.

Leach, J. C., \& Melicher, R. W. (2011). Entrepreneurial finance. Cengage Learning.

López Salazar, A., Contreras Soto, R., \& Espinosa Mosqueda, R. (2012). The impact of financial decisions and strategy on small business competitiveness. Global Journal of Business Research, 6(2), 93-103.

Love, J. H., \& Roper, S. (2015). SME innovation, exporting and growth: A review of existing evidence. International Small Business Journal, 33(1), 28-48.

Love, J. H., Roper, S., \& Zhou, Y. (2016). Experience, age and exporting performance in UK SMEs. International Business Review, 25(4), 806-819.

Lu, J. W., \& Beamish, P. W. (2001). The internationalization and performance of SMEs. Strategic Management Journal, 22(6-7), 565-586.

Mac an Bhaird, C., \& Lucey, B. (2010). Determinants of capital structure in Irish SMEs. Small Business Economics, 35(3), 357-375.

Makadok, R., \& Ross, D. G. (2013). Taking industry structuring seriously: A strategic perspective on product differentiation. Strategic Management Journal, 34(5), 509-532.

Martineau, C., \& Pastoriza, D. (2016). International involvement of established SMEs: A systematic review of antecedents, outcomes and moderators. International Business Review, 25(2), 458-470.

Morgan-Thomas, A., \& Jones, M. V. (2009). Post-entry internationalization dynamics: differences between SMEs in the development speed of their international sales. International Small Business Journal, 27(1), 71-97.

Rasheed, H. S. (2005). Foreign entry mode and performance: The moderating effects of environment. Journal of Small Business Management, 43(1), 41-54.

Rasheed, R., \& Siddiqui, S. H. (2019). Attitude for inclusive finance: influence of owner-managers' and firms' 
characteristics on SMEs financial decision making. Journal of Economic and Administrative Sciences.

Rita, M. R., \& Huruta, A. D. (2020). Financing Access and SME Performance: A Case Study from Batik SME in Indonesia. International Journal of Innovation, Creativity and Change, 12(12), 203-224.

Rita, M. R., \& Utomo, M. N. (2019). An entrepreneurial finance study: MSME performance based on entrepreneurial and financial dimensions. Jurnal Keuangan dan Perbankan, 23(2), 217-234.

Rogers, S., \& Makonnen, R. (2014). Entrepreneurial finance: Finance and business strategies for the serious entrepreneur.

Shehu, A., Ibrahim, M. A., Mat, N., Nasiru, A., Popoola, O., Muhammad, M., \& Kura, K. M. (2013). The mediating effect between some determinants of SME performance in Nigeria. Management, 3(4), 237-242.

Sholihin, M., \& Ratmono, D. (2013). Analisis SEM-PLS dengan Warp PLS 3.0 untuk Hubungan Nonlinier dalam Penelitian Sosial dan Bisnis. Yogyakarta: Penerbit ANDI.

Stiebale, J. (2011). Do financial constraints matter for foreign market entry? A firm-level examination. The World Economy, 34(1), 123-153.

Storey, D. (1994). Understanding the Small Business Sector Routledge. London, UK.

Ter Wengel, J., \& Rodriguez, E. (2006). SME export performance in Indonesia after the crisis. Small Business Economics, 26(1), 25-37.

Timmons, J., \& Spinelli, S. (2004). New venture strategies: Entrepreneurship for the 21st century. Burr Ridge, IL: Irwin-McGraw-Hill Publishers.

Todd, P. R., \& Javalgi, R. G. (2007). Internationalization of SMEs in India: Fostering entrepreneurship by leveraging information technology. International Journal of Emerging Markets, 2(2), 166-180.

Uly, Y. A. (2019, 21 June 2019). UKM Indonesia yang Tembus Pasar Ekspor Baru 10\%. Oke Finance.

Wingwon, B. (2015). Effect of Entrepreneurship, Business Strategy and Business Networking toward Competitive Advantage fo Small and Medium Enterprises in Thailand. International Journal of Entrepreneurship and Small Business, 26(2), 217-232.

Zhou, L., Wu, W.-p., \& Luo, X. (2007). Internationalization and the performance of born-global SMEs: the mediating role of social networks. Journal of International Business Studies, 38(4), 673-690.

\section{Copyrights}

Copyright for this article is retained by the author(s), with first publication rights granted to the journal.

This is an open-access article distributed under the terms and conditions of the Creative Commons Attribution license (http://creativecommons.org/licenses/by/4.0/). 